\section{Brown rot on nuts of Castanea sativa Mill: an emerging disease and its causal agent}

\author{
Giorgio Maresi $^{(1)}$, Claudia Maria Oliveira Longa ${ }^{(2)}$, Tullio Turchetti ${ }^{(3)}$
}

The quality and quantity of nut production are fundamental to the economic viability of chestnut cultivation, yet recent reports indicate that severe damage due to moulds represents a significant problem for growers. We carried out an investigation of the agents of chestnut rot and internal fruit damage in three orchards in Italy. Black and brown rot, as well as insect damage, were found in all the areas examined. Brown rot appeared to be the main cause of damage, affecting $8 \%$ to $49 \%$ and $2 \%$ to $24 \%$ of nuts collected from the ground and from burrs, respectively. With respect to morphology and DNA sequencing analyses, fungal isolates obtained from brown rot were homologous with Gnomoniopsis sp. obtained from Dryocosmus kuriphilus (Yasumatsu) galls and with Gnomoniopsis castanea and Gnomoniopsis smithogilvyi described on chestnut in Italy and Australia, respectively. The same fungus was also isolated from the bark of one- and two-years-old healthy shoots at each site, supporting the endophytic behaviour of this rot agent. Brown rot symptoms on nuts associated with Gnomoniopsis sp. corresponded with those previously described by several authors and referred to as Phoma or Phomopsis endogena, suggesting a relationship between these fungi and Gnomoniopsis sp. It is to notice that the escalation of brown rot damage in Italy followed several periods of drought and probably the recent invasion of $D$. kuriphilus, both stress factors for chestnut trees.

Keywords: Nut mould, Gnomoniopsis sp., Phoma endogena, Phomopsis castanea, endophytism

\section{Introduction}

Chestnut cultivation has progressed in Italy and other European countries as a result of a favourable market and the recovery of trees following natural establishment of hypovirulence in chestnut blight (Turchetti et al 2008). Chestnut orchards and stands are still vital to the economy of many mountain communities as elements of the landscape, sources of timber and, in particular, for the production of nuts. The quality of chestnuts is determined by size, shape, color, flavor and texture, features which are very important for both fresh consumption and processing (Korel \& Balaban 2008) and which are essential to ensuring an advantageous income for growers. These fruits contain sugars, especially monosaccharides and disaccharides such as sucrose, glucose, fructose and raffinose, as well as starch (Bernardez et al. 2004). As a consequence, they are highly attractive to insects and fungi, which can cause severe damage and hence pose a considerable problem for chestnut cultivation. Attacks by insect larvae (e.g., Cydia splendana $\mathrm{Hb}$., Cydia fagiglandana Zell. and Curculio elephans Gyll.) are well known to be detrimental to the harvesting of healthy chestnut fruits (Pedrazzoli et al. 2012 ). Several fungi are also capable of colonizing nuts and causing damage: Phoma endogena Speg. and Phomopsis endogena Speg. Cif. have been
(1) FEM-IASMA - Centre for Technology Transfer, v. E. Mach 1, I-38010 San Michele all'Adige (TN - Italy); (2) FEM-IASMA - Research and Innovation Centre, Sustainable AgroEcosystems and Bioresources Department, v. E. Mach 1, I-38010 San Michele all'Adige (TN Italy); (3) Institute of Plant Protection (IPP-CNR), v. Madonna del Piano 10, I-50019 Sesto Fiorentino (FI - Italy).

\section{@ Giorgio Maresi (giorgio.maresi@fmach.it)}

Received: Jan 21, 2013 - Accepted: Apr 19, 2013

Citation: Maresi G, Oliveira Longa CM, Turchetti T, 2013. Brown rot on nuts of Castanea sativa Mill: an emerging disease and its causal agent. iForest 6: 294-301 [online 2013-07-16] URL: http://www.sisef.it/iforest/contents/?id=ifor0952-006

Communicated by: Alberto Santini described as agents of brown rot, Sclerotinia pseudotuberosa Rehm (syn. Ciboria batschiana Zopf) can cause black rot, while Penicillium spp. and Penicillium crustaceum L. Fr. produce greenish moulds. Environmental factors can also influence the quality of fruits (Ferreira-Cardoso \& De Vasconcelos 2009): low soil water availability and high temperatures are destabilizing factors for normal chestnut growth as they are responsible for decreased plant vigor and substandard fruit production and also exacerbate the effect of pest and fungi damage (GomesLaranjo et al. 2004, Conedera et al. 2005).

The recent appearance of the invasive Asian chestnut gall wasp (Dryocosmus kuriphilus Yasumatsu) in Italian chestnut stands and orchards is causing new concern for the sustainability of chestnut cultivation (Bosio et al. 2010). An unusual level of fruit damage was reported in Piedmont, more or less in correspondence with the wasp invasion, (Gentile et al. 2010) and subsequently in other chestnut-producing areas of Italy, such as Trentino, Emilia Romagna, Tuscany, Lazio and Campania (Maresi, Poli \& Sigillo, personal comm.). The damage in Piedmont was initially attributed to in Gnomonia pascoe (Gentile et al. 2010) and recently related to Gnomoniopsis castanea, a proposed new species (Visentin et al. 2012). Attacks of brown rot have also occurred in chestnut cultivations in Australia, where the agent was identified as Gnomoniopsis smithogilvyi (Shuttleworth et al. 2012). Gnomoniopsis sp. has been found to be associated with necrosis of D. kuriphilus galls (Magro et al. 2010), raising interest in its use as a biocontrol agent against this hymenopteran (Vannini et al. 2012).

In this study, we investigated brown rot damage reported in three different Italian chestnut-growing areas in Piedmont, Trentino and Tuscany with the aim of isolating and identifying the causal agents, verifying their homology, comparing their morphology, testing their pathogenicity and formulating hypotheses regarding the factors responsible for their spread.

\section{Material and methods}

Study sites and their environmental features

Chestnut orchards were selected in October 2011 in three Italian regions: Boarda (Val di Susa, Turin, Piedmont), Montesenario ( $\mathrm{Mu}-$ gello, Florence, Tuscany) and Crosano (Val d'Adige, Trento, Trentino-South Tyrol). The general environmental features of each stand are reported in Tab. 1.

Monthly mean temperatures and accumulated precipitation for 2011 were obtained from the meteorological stations closest to each of the study sites: Castel Borello (630 
Tab. 1 - Main environmental features of the study sites.

\begin{tabular}{lccc}
\hline Site & Boarda & Montesenario & Crosano \\
\hline Elevation (m a.s.1.) & 565 & 650 & 550 \\
Exposure & North & North West & North East \\
Morphology & Terrace & Terrace & Slope \\
Slope & $0 \%$ & $5 \%$ & $15 \%$ \\
Substrate & Alluvial & Sandstone & Turbidite \\
Management & cultivated & Semi-cultivated & Semi-cultivated \\
Irrigation & Twice (July, August) & absent & absent \\
Geographic & $45.120369 \mathrm{~N}$ & $43.891551 \mathrm{~N}$ & $45.827764 \mathrm{~N}$ \\
coordinates & $7.187719 \mathrm{E}$ & $11.330627 \mathrm{E}$ & $10.975599 \mathrm{E}$ \\
\hline
\end{tabular}

$\mathrm{m}$ a.s.1. - Società Meteorologica Italiana network), Borgo San Lorenzo (193 m a.s.l. LaMMA network), and Besagno (382 m a.s.1. - FEM agro meteorological network). Only raw, non-validated, non-gap-filled meteorological data series were used. For Besagno, monthly mean temperatures and accumulated precipitation recorded during the vegetative period (April-September) were extracted from data for the whole period 2001-2011. These monthly values were compared with the average of the 10 years data series.

\section{Sample collection and laboratory testing}

Three chestnut trees were randomly selected in each of the orchards investigated. Forty nuts were collected from burrs still attached to the branches of each tree and sixty nuts were collected from the ground under the same trees. Burrs were examined for perithecia presence. Fruit samples were packaged separately in paper bags and immediately transferred to the laboratory for assays. Each nut was dissected and examined: fruits showing brown rot were separated from nuts affected by black rot and selected for isolation. A further 10 nuts were collected from ground in each area, stored in field conditions and evaluated for the presence of fruiting bodies.

Ten shoots were randomly collected from the crown of each tree, placed in plastic bags and stored at $4{ }^{\circ} \mathrm{C}$ for laboratory assay.

\section{Fungal isolation and identification}

\section{(A) From nuts}

Tissue from the initial decaying endosperm and from mummified fruits were surfacesterilized for $1 \mathrm{~min}$ in $70 \%$ ethanol, $5 \mathrm{~min}$ in $1.25 \%$ sodium hypochlorite and $30 \mathrm{sec}$ in $70 \%$ ethanol. They were then rinsed twice in sterile, distilled water and blotted on dry sterile filter paper. Using a sterile scalpel, fragments of infected tissue were plated onto Potato Dextrose Agar (Difco, USA) containing biotin $(1 \mathrm{mg} / \mathrm{l})$ and methionine $(100$ $\mathrm{mg} / \mathrm{l}$ - PDAmb) and incubated in Petri dishes in the dark at $25 \pm 1^{\circ} \mathrm{C}$ for seven days.

Fungal cultures were sub-cultured onto

\section{PDAmb in the dark at $25^{\circ} \mathrm{C}$.}

Morphological observation of colonies was carried out with an SMZ1000 stereomicroscope (Nikon, USA), while microscopic feament of conidia, were observed with an Eclipse 80i microscope (Nikon). Measurements of 50 pycnidia and 50 conidia of one strain from each area plus 50 conidia collected from fructifications on nuts were made from digital sight images (DS-L2 imaging controller, Nikon, USA).

Brown rot mycelium was placed in $10 \mathrm{ml}$ of sterilized tap water and shaken. One $\mathrm{ml}$ of conidial suspension $\left(2 \times 10^{3}\right.$ conidia $\left.\mathrm{ml}^{-1}\right)$ was diluted 1:5 with sterile tap water and plated on Petri dishes containing PDAmb substrate. Individual germinated conidia were collected under sterile conditions with a micro-needle using a stereomicroscope then transferred to plates and incubated under the conditions reported above. Thirty six individual conidial strains from each area were examined for morphological characteristics.

\section{(B) From shoots}

An $8-10 \mathrm{~cm}$ section was cut from each shoot of the current years' and the two-year growth. Each sample was surface disinfested for $10 \mathrm{sec}$ in $95 \%$ ethanol followed by $4 \mathrm{~min}$ in $2 \% \mathrm{NaOCl}$ solution with 2 drops of Tween $80 l^{-1}$ (Stanosz et al. 2001). Ten fragments were cut from various positions on the bark tissue of each sample and placed on potato dextrose agar (PDA, Oxoid) in Petri dishes, five in each dish.

Isolations were incubated at $25 \pm 1{ }^{\circ} \mathrm{C}$ for 7 days in the dark, after which the growing fungi were identified by their cultural characteristics. The number of fragments colonized by each type of culture was linked with the original sample and plot.

\section{DNA analysis}

DNA assays were carried out using cultures from individual monoconidial strains randomly selected from each area, two from Crosano and one from each of the other sites. Genomic DNA was extracted from approximately $50 \mathrm{mg}$ of mycelia scraped from the surface of a 7-10 days culture growing tures, such as size, shape, color and arrange- on PDAmb. DNA was also extracted directly from initial decaying, brown tissue and chalky tissues in symptomatic nuts from Crosano. A total of seven strains were so assayed.

DNA was extracted using the NucleoSpin1 Plant Kit according to the manufacturer's instructions (Macherey-Nagel, Düren, Germany). Internal transcribed spacer regions 1 and 2 , including the $5.8 \mathrm{~S}$ rDNA, were amplified and sequenced using the primers ITS5 and ITS4 (White et al. 1990). Gene fragments were amplified in $25 \mu \mathrm{l}$ reactions on a GeneAmp 9700 thermal cycler (Applied Biosystems, Foster City, CA) under the following reaction conditions: $12.5 \mu \mathrm{l}$ of GoTaq Green Master Mix (supplied in 2X Green GoTaq ${ }^{\circledR}$ Reaction Buffer $\mathrm{pH} 8.5,400 \mu \mathrm{M}$ of each dNTPs and $3 \mathrm{mM} \mathrm{MgCl}_{2}$ - Promega, USA), $0.40 \mu \mathrm{M}$ of each primer, $10 \mathrm{ng}$ of DNA template and $9.5 \mu \mathrm{l}$ of nuclease free water. The thermal cycler programme was: $2 \mathrm{~min}$ at $95^{\circ}$ $\mathrm{C}$ followed by 30 cycles of $30 \mathrm{sec}$ at $95^{\circ} \mathrm{C}$, $30 \mathrm{sec}$ at $55^{\circ} \mathrm{C}$, and $1 \mathrm{~min}$ at $72{ }^{\circ} \mathrm{C}$, with a final extension period of $10 \mathrm{~min}$ at $72{ }^{\circ} \mathrm{C}$. Amplification products were separated by electrophoresis on $1 \%$ agarose gel at $100 \mathrm{~V}$ for 30 minutes in TBE buffer (Tris-borate EDTA). The gel was stained with SyberSafe (Applied Biosystems, California, USA) and visualized on a UV transilluminator (Biorad) to asses PCR amplification.

PCR products were purified using ExoSAP (Euroclone S.p.A., Italy) following the manufacturer's instructions. Amplified products were sequenced with the Big Dye terminator v3.1 cycle sequencing kit (Applied Biosystems, Foster City, CA, USA) on an Applied Biosystems 3130xl Genetic Analyzer. BLASTN comparison of the amplicon sequences was carried out using the NCBI database to confirm the identity of the strains. Raw sequences were edited using Sequencer version 4.5 for Windows (Gene Codes Corporation, Ann Arbor, MI, USA) and deposited in the GenBank.

Nucleotide sequences were aligned with other fungal sequences (Gnomoniopsis spp., Phomopsis spp. and Phoma spp.) from NCBI using the Mega 4.1 software (http://www.megasoftware.net). A distance matrix was generated and an evolutionary tree for the datasets was inferred by the neighbor-joining method. The stability of relationships was assessed by bootstrap analysis of the neighbor-joining data based on 1000 replicates.

\section{Artificial inoculation on nuts}

Some 105 asymptomatic nuts were collected in a chestnut orchard near Trento (Lisignago), where no brown rot symptoms have been recorded until now. A small sample (15 nuts) was randomly chosen and dissected to confirm healthy status. Sixty of the remaining nuts were surface-sterilized for $1 \mathrm{~min}$ in 
$70 \%$ ethanol, 5 min in $1.25 \%$ sodium hypochlorite, $30 \mathrm{sec}$ in $70 \%$ ethanol and rinsed in sterilized tap water. After this treatment, the fruits were artificially infected with each of the monoconidial strains selected for the DNA assay. An artificial wound $0.5 \mathrm{~cm}$ deep was made in the pericarp at the apical part of the fruit using a sterilized scalpel, as reported by Voglino \& Bongini (1917). A fragment of mycelium collected from a ten-dayold culture was placed in the wound, which was then covered with masking tape; the nuts were then stored in Petri dishes $(25 \mathrm{~cm}$ in diameter). Fifteen replicates were run for each strain, another fifteen were wounded but not inoculated to serve as controls. The remaining fifteen unsterilized nuts were wounded as additional controls. All the treated and untreated nuts were stored at 25 ${ }^{\circ} \mathrm{C}$ in the dark. After twenty days all replicates were examined for disease and re-isolations were carried out from the symptomatic nuts on plates containing PDAmb.

\section{Statistical analysis}

The statistical analysis concerned the symptoms presence and isolations from nuts and shoots. For each symptom detected on nuts, considering the mean value of the three sampled trees, the three sites were compared using the Chi-square $\left(\chi^{2}\right)$ test for 2-way tables (coupling the sites two by two). The same analysis was used for fungal isolation from bark tissue of shoots. $\chi^{2}$ values were compared with critical $\chi^{2}$ value at significance level $\alpha=0.05$ and 1 degree of freedom.

\section{Results}

Study sites and environmental features

The three sites, located at similar altitudes, vary in exposure and morphology (Tab. 1). They are characterized by three different, but mainly acidic, geological substrates (Alluvial, Sandstone and Turbidite). Different management systems are in operation in the three orchards: Boarda is regularly cultivated (pruned and mowed) and irrigated twice during the summer, while Montesenario and Crosano are partially cultivated: mowing and harvesting are the only agricultural practices employed.

During 2011, high temperatures (over 20 $\left.{ }^{\circ} \mathrm{C}\right)$ were recorded for August and September, while in the same months rainfall was less than 100 millimeters at all three stations (Fig. 1). In Besagno, August and September 2011 monthly mean temperatures were higher ( 1.3 and $2.7^{\circ} \mathrm{C}$, respectively) than the average of 10 years series for the same months (data not showed), while precipitations were lower of about $20 \mathrm{~mm}$ with respect to the same months and about $50 \mathrm{~mm}$ less for April and May. June and July were wetter with precipitations higher by $50 \mathrm{~mm}$ more than the 10 years series average for the same months (data not shown).

D. kuriphilus galls were observed in abundance at all the study sites.

Sample collection and description of symptoms

Significant differences were found between healthy fruits collected from the ground at Crosano and those collected at the other two sites (Tab. 2). The percentages of nuts displaying insect damage collected from the trees and from the ground was recorded for each of the study sites (range 15-23\%). C. splendana and $C$. fagiglandana larvae were detected in the affected nuts and fungal rot associated with larval galleries was also observed.

The main symptoms recorded in the remaining rotten nuts of the samples were of black rot (Fig. 2a) and brown rot (Fig. 2b).

Initial and final symptoms coexisted in most of the nuts and, in a few cases, black and brown rot were observed together. Both rots were present in the nuts collected from the ground and in those still on the trees, although the extent of damage was greater in the nuts on the ground: black rot affected $8 \%$ of nuts gathered from the ground and $2 \%$ of nuts on the trees in the Boarda area, while the figures for Montesenario were $7 \%$ and

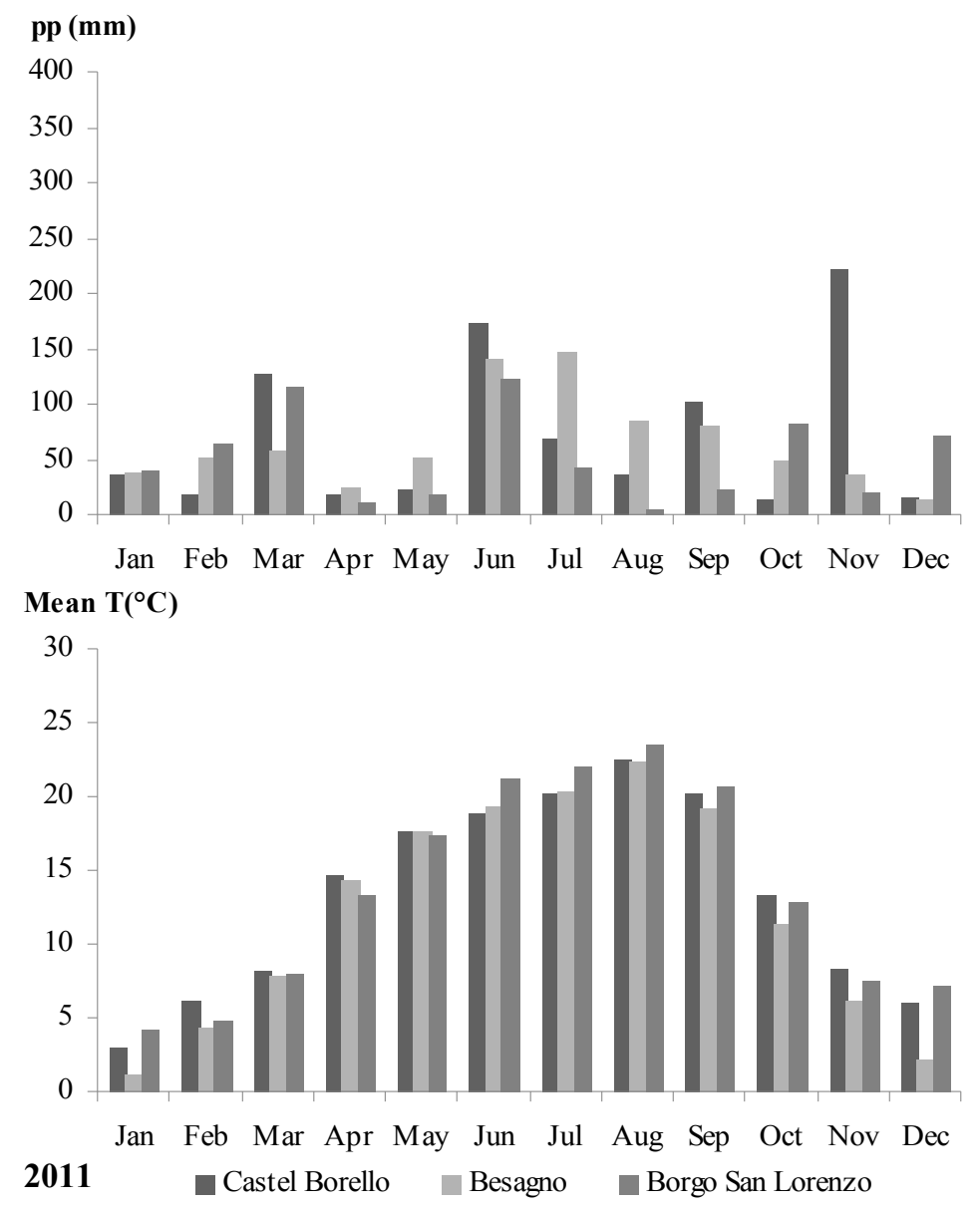

Fig. 1 - Monthly precipitation and mean temperatures recorded during 2011 at the three meteorological stations closest to the study sites.

Tab. 2 - Percentages of damaged nuts found in the samples collected from the three different chestnut orchards. Chi-squared test 2 -way tables was performed. Critical $\chi^{2}$ value was at $\alpha=0.05$ and $\mathrm{df}=1 .(*)$ : values which differ in a significant way.

\begin{tabular}{lrrrrrr}
\hline \multirow{2}{*}{ Symptoms } & \multicolumn{3}{c}{ Nuts from the ground } & \multicolumn{3}{c}{ Nuts from burrs } \\
\cline { 2 - 7 } & Boarda & Montesenario & Crosano & Boarda & Montesenario & Crosano \\
\hline No Symptoms (\%) & 62 & 65 & 32 & 81 & 72 & 56 \\
Black rot (\%) & 8 & 7 & 3 & 2 & 1 & 0 \\
Brown rot (\%) & 11 & 8 & $49^{*}$ & 2 & 4 & $24^{*}$ \\
Insect damage (\%) & 19 & 20 & 16 & 15 & 23 & 20 \\
\hline
\end{tabular}



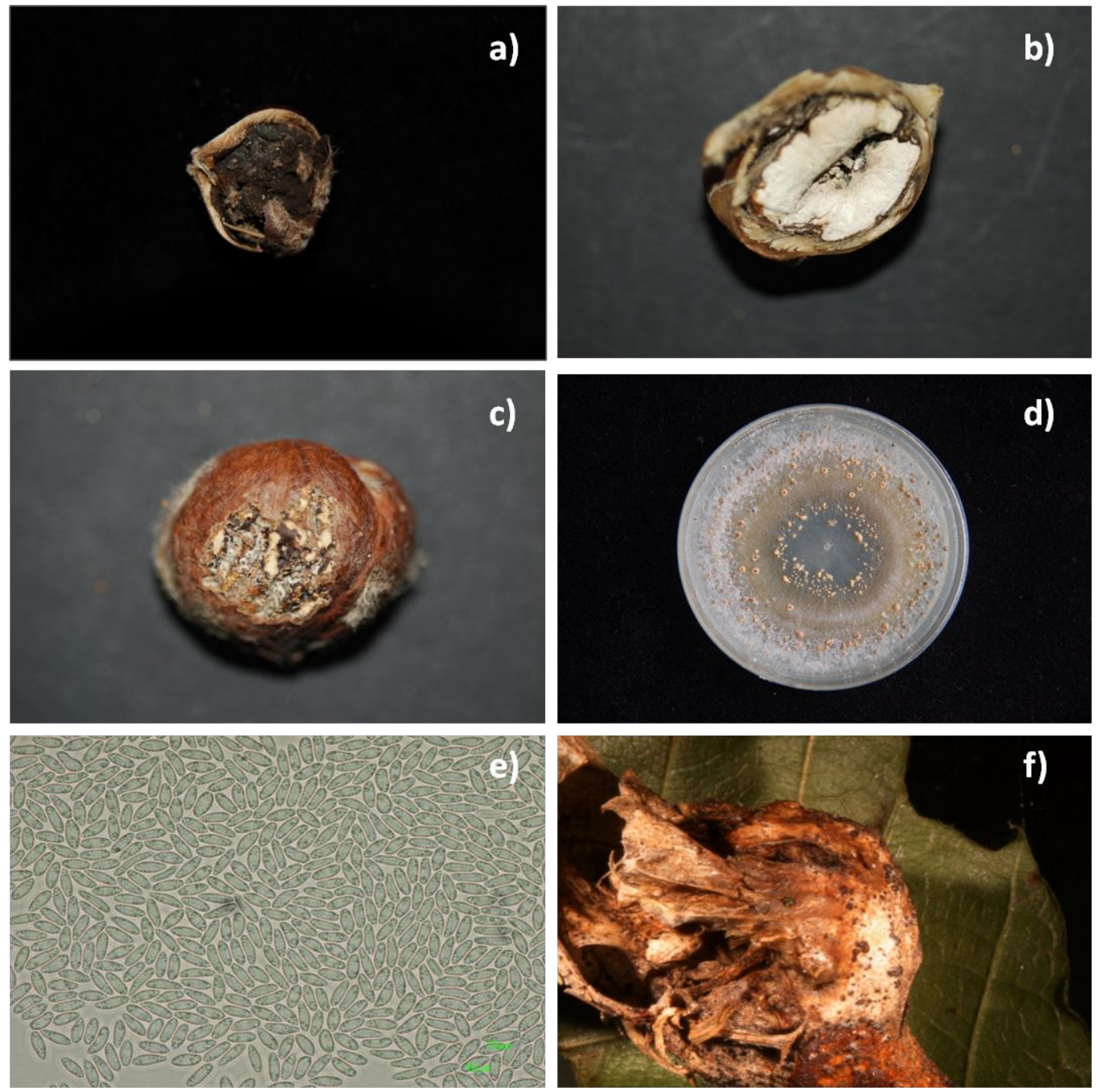

Fig. 2 - (a) Nut completely destroyed by black rot due to Sclerotinia pseudotuberosa: it generally starts in the torch, producing grey coloration on the endosperm that rapidly turns blackish with evidence of black mycelium in the rotten tissue. (b) Nut affected by brown rot: the fungus initially causes light brown coloration on the margin of the endosperm, followed by loss of tissue consistency as it whitens and hardens, resulting in a chalky appearance. (c) Black pycnidia from brown rot tissue erupting below the episperm. (d) Culture of Gnomoniopsis sp.: colony on PDAmb. (e) Conidia obtained from stroma or pycnidia in cultures and from pycnidia on nuts. (f) Pycnidia of Gnomoniopsis sp. on Asian chestnut wasp gall.
$1 \%$, respectively, and for Crosano $3 \%$ and $0 \%$, without significant differences among sites (Tab. 2).

Brown rot was widespread in the Crosano area, where $49 \%$ of the nuts from the ground and $24 \%$ of the nuts from the trees showed symptoms. In this stand, the disease was significantly more present than in the other two sites either in nuts taken from the ground ( vs. Boarda: $\chi^{2}=19.21, \mathrm{p}<0.05 ; v s$. Montesenario: $\left.\chi^{2}=23.64, \mathrm{p}<0.05\right)$ or from the burrs $\left(\chi^{2}=6.27, \mathrm{p}<0.05\right)$. The brown rot

Tab. 3 - Comparison of conidiomata, conidia and cultural characteristics of fungi associated with brown rot obtained in this study compared with other findings reported in the literature. All studies cited reported the fungus on Castanea sativa. (n.r.): not reported.

\begin{tabular}{|c|c|c|c|c|c|}
\hline Strains & $\begin{array}{l}\text { Perithecia } \\
(\mu \mathrm{m})\end{array}$ & $\begin{array}{c}\text { Conidiomata } \\
(\mu \mathrm{m})\end{array}$ & $\begin{array}{c}\text { Conidia } \\
(\mu \mathrm{m})\end{array}$ & Cultural morphology & Symptoms \\
\hline $\begin{array}{l}\text { Gnomoniopsis sp. } \\
\text { (this study) }\end{array}$ & - & $200 \times 158$ & $\begin{array}{l}5.1-8.9 \times \\
1.9-3.9\end{array}$ & $\begin{array}{l}\text { Light brown mycelium. Orange masses of } \\
\text { conidiomata in concentric rings }\end{array}$ & $\begin{array}{l}\text { Brown rot, } \\
\text { endophytic on shoots }\end{array}$ \\
\hline $\begin{array}{l}\text { Phoma endogena } \\
\text { (Spegazzini 1879) }\end{array}$ & n.r. & n.r. & $6-8 \times 2-3$ & Not reported & Brown rot \\
\hline $\begin{array}{l}\text { Phoma endogena } \\
\text { (Voglino \& Bongini } \\
\text { 1917) }\end{array}$ & - & $200 \times 160$ & $6-7.5 \times 2.4$ & $\begin{array}{l}\text { Light brown mycelium. Orange masses of } \\
\text { conidiomata in concentric rings }\end{array}$ & Brown rot \\
\hline $\begin{array}{l}\text { Phoma endogena } \\
\text { (Ridé \& Gudin 1960) }\end{array}$ & - & n.r. & $8.1 \times 2.4$ & White mycelium in concentric rings & $\begin{array}{l}\text { Brown rot, necrosis } \\
\text { on shoots and leaves }\end{array}$ \\
\hline $\begin{array}{l}\text { Gnomoniopsis sp. } \\
\text { (Magro et al. 2010) }\end{array}$ & - & n.r. & $\begin{array}{l}5.5-8.0 \times \\
2.0-3.0\end{array}$ & $\begin{array}{l}\text { Light brown mycelium. Orange conidiomata } \\
\text { in concentric rings }\end{array}$ & $\begin{array}{l}\text { Colonisation of } D \text {. } \\
\text { kuriphilus galls }\end{array}$ \\
\hline $\begin{array}{l}\text { Gnomoniopsis } \\
\text { castanea (Visentin et } \\
\text { al. 2012) }\end{array}$ & - & $\begin{array}{c}244-268 x \\
146-190\end{array}$ & $\begin{array}{l}4.9-7.3 \times \\
2.4-3.7\end{array}$ & $\begin{array}{l}\text { Greyish brown mycelium with concentric } \\
\text { rings of conidial stroma }\end{array}$ & $\begin{array}{l}\text { Brown rot, } \\
\text { endophytic on shoots }\end{array}$ \\
\hline $\begin{array}{l}\text { Gnomoniopsis smitho- } \\
\text { gilvyi (Shuttleworth et } \\
\text { al. 2012) }\end{array}$ & $238-242$ & - & $\begin{array}{l}6.5-9.5 \mathrm{x} \\
2.0-4.0\end{array}$ & $\begin{array}{l}\text { Greyish brown mycelium with concentric } \\
\text { rings of conidial stroma }\end{array}$ & $\begin{array}{l}\text { Brown rot, } \\
\text { endophytic on shoots }\end{array}$ \\
\hline
\end{tabular}


was also present in the other areas without significant differences: in Boarda $11 \%$ of the nuts from the ground and $2 \%$ of the nuts from the trees were affected, while in Montesenario the figures were $8 \%$ and $4 \%$, respectively. In neither of these areas the disease was observed in previous years. No differences between the three sites were observed for insect damage.

Storage of the nuts, whether controls or producing fruiting bodies in natural conditions, exacerbated the brown rot as all the fruits displayed chalky tissue after three months. An abundance of pycnidia, first brownish-grey then blackish, appeared on the surface of the endosperm below the episperm (Fig. 2c). These fructifications were also observed in the invaginations and inside the endosperm where holes and cavities in the rotten tissue were detected. Conidia collected from these pycnidia were analogous to those obtained from the cultures (Tab. 3). No perithecia were observed on collected burrs and on infected nuts.

\section{Fungal isolation and identification}

Cultures of greyish-black mycelia were isolated from black rot tissue and identified as the species Sclerotinia pseudotuberosa (syn. Ciboria batschiana, anamorph Rhacodiella castaneae) according to the morphological diagnostic criteria described by Ellis \& Ellis (1997)

Colonies with light brown mycelium were isolated from initial brown tissue and white, chalky tissue. Orange masses of conidial growth appeared in concentric rings on the surface of the cultures (Fig. 2d). On older colonies, blackish, ellipsoid pycnidia (158$200 \mu \mathrm{m})$ also produced conidia, which were generally ovoid, oval or oblong (5.15-8.91 $\mu \mathrm{m} \times 1.90-3.96 \mu \mathrm{m}-$ Fig. 2e). Based on the above characteristics the fungus was identified as Gnomoniopsis sp. (Tab. 3). Homogeneous morphological characteristics were found in all the monoconidial strains from all the study sites. Observed differences in size between conidia produced on chestnut fruits and those produced on nutritive media were non-significant.

High percentages of positive isolation were obtained from the bark tissue of both oneyear and two-years-old shoots at each site (Tab. 4). Most of the colonies displayed the same characteristics as the fungus obtained from isolations from brown rot nuts. As for 1 -year-old shoots, Crosano recorded the highest presence of Gnomoniopsis with respect to the Boarda and Montesenario $\left(\chi^{2}=\right.$ 21.9 and 27.4, respectively; $\mathrm{p}<0.05$ ). Colonies of the brown rot agent were found on $70 \%$ of the fragments, on average. Boarda (33\%) and Montesenario (48\%) showed similar values as for one-year-old shoots, while they differed for 2-years-old shoots $\left(\chi^{2}=4.67 ; \mathrm{p}<0.05\right)$. Sporadic isolates of
Tab. 4 - Mean percentage of fungi isolations from bark tissue of healthy shoots (one- and two-years old) of chestnut plants. The Chi-squared test for 2 way table was performed (presence/no presence for each isolate and coupled sites). Critical $\chi^{2}$ value at $\alpha=0.05$ and $\mathrm{df}=1$. (*): values which differ in a significant way.

\begin{tabular}{llccc}
\hline Shoots & Species & Crosano & Montesenario & Boarda \\
\hline 1 year old & Gnomoniopsis sp. & $70^{*}$ & 33 & 37 \\
& Cryphonectria parasitica & 0 & 1 & 0 \\
& other fungi & $21^{*}$ & 4 & 9 \\
& Sterile fragments & 9 & 61 & 55 \\
\hline 2 years old & Gnomoniopsis sp. & $71^{*}$ & $48^{*}$ & 33 \\
& Cryphonectria parasitica & 4 & 1 & 3 \\
& other fungi & $17^{*}$ & 4 & 9 \\
& Sterile fragments & 9 & 47 & 55 \\
\hline
\end{tabular}

Cryphonectria parasitica were obtained, by other authors (Spegazzini 1879, Voglino though no differences in frequencies were \& Bongini 1917, Ridé \& Gudin 1960, observed among sites. Crosano recorded also Magro et al. 2010, Visentin et al. 2012, a presence of other fungi higher than Shuttleworth et al. 2012).

Montesenario in one-year and two-years-old shoots $\left(\chi^{2}=13.21\right.$ and 8.99 , respectively; $\mathrm{p}<0.05)$. Tab. 3 reports a comparison of the morphological characteristics of these isolates of Gnomoniopsis sp. with those of fungi associated with the same symptoms reported

\section{DNA analysis}

Morphological identification of fungal isolates was confirmed with molecular data obtained from DNA amplification. Four ITS sequences obtained from the DNA of fungal

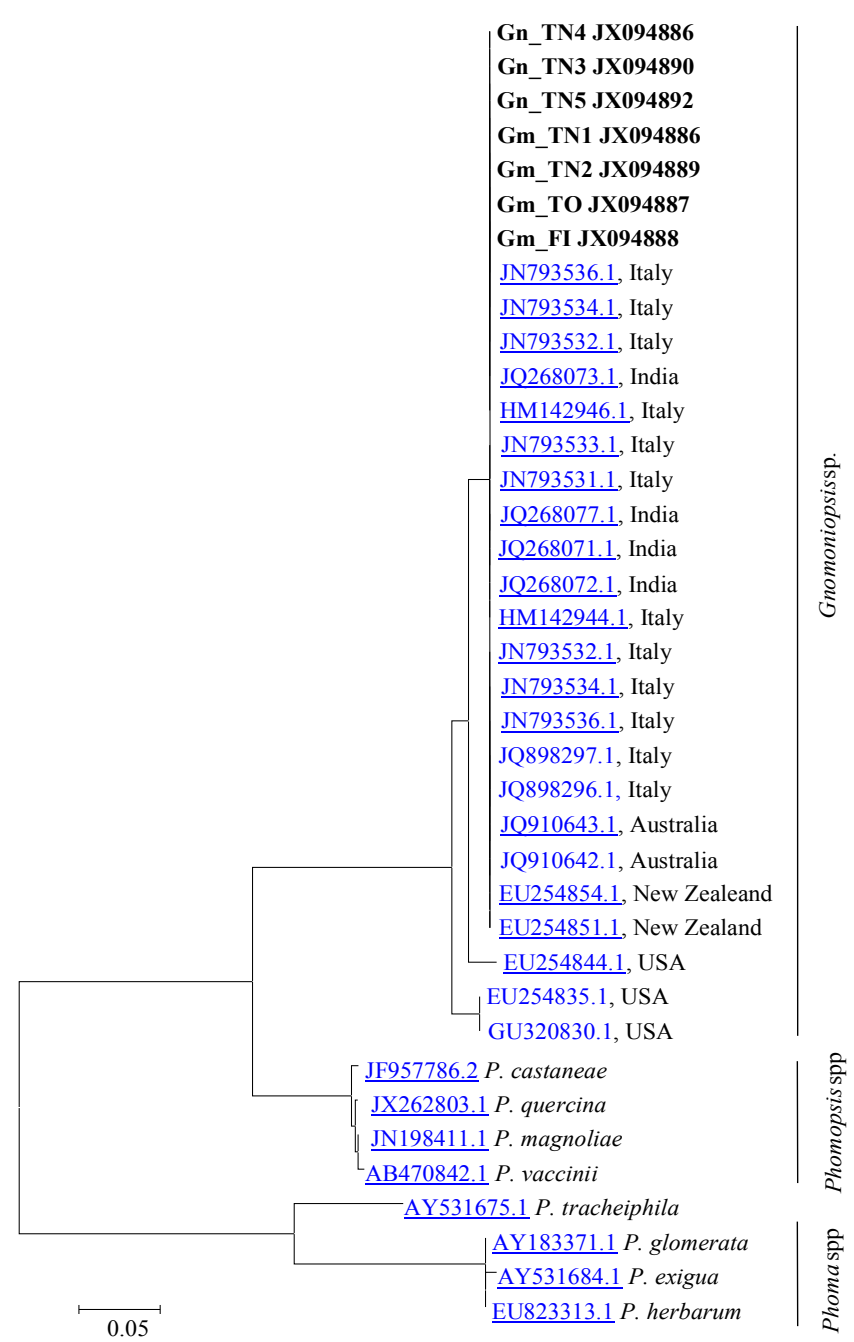

Fig. 3 - Dendrogram showing the similarities between amplificates from mycelium isolates and nut tissue samples (boldface) and sequences in the NCBI database created by the CLUSTALW software. 
Tab. 5 - Database matches for sequences generated from ITS 5 and ITS 4 PCR products, derived from tissue showing symptoms of brown rot and mycelia of monoconidial cultures.

\begin{tabular}{lllc}
\hline Isolate & DNA origin & Description & $\begin{array}{c}\text { Max ident. } \\
\text { (\%) }\end{array}$ \\
\hline Gm_TN1 & Trentino mycelium & Gnomoniopsis sp. M6EmB (JN793536.1) & 99 \\
Gm_TO & Piedmont mycelium & Gnomoniopsis sp. M6EmB (JN793536.1) & 100 \\
Gm_FI & Tuscany mycelium & Gnomoniopsis sp. M6EmB (JN793536.1) & 99 \\
Gm_TN2 & Trentino mycelium & Gnomoniopsis sp. M6EmB (JN793536.1) & 99 \\
Gn_TN3 & Chalky tissue & Gnomoniopsis sp. M6EmB (JN793536.1) & 99 \\
Gn_TN4 & Brown tissue & Gnomoniopsis sp. M6EmB (JN793536.1) & 99 \\
Gn_TN5 & Initial brown tissue & Gnomoniopsis sp. M6EmB (JN793536.1) & 99 \\
\hline
\end{tabular}

Tab. 6 - Results of the artificial inoculation tests. $(*)$ : 13\% (2 nuts) affected by Penicillium spp.

\begin{tabular}{lcc}
\hline Strain & $\begin{array}{c}\text { \% nuts affected } \\
\text { by brown rot }\end{array}$ & $\begin{array}{c}\text { \% } \\
\text { asymptomatic }\end{array}$ \\
\hline Gm_TN1 & 71 & 29 \\
Gm_TN2 & 72 & 28 \\
Gm_FI & 62 & 38 \\
Gm_TO & 61 & 39 \\
Control (disinfected and wounded) & 0 & 100 \\
Control (not disinfected, wounded) & 0 & $87^{*}$ \\
\hline
\end{tabular}

cultures and three sequences obtained directly from nut tissue were analyzed. A Megablast search in NCBI revealed the above fungal specimens having the highest similarity with the Gnomoniopsis sp. strain M6EmB (JN793536.1), with identity rates in the range of $99-100 \%$ (Tab. 5).

Phylogenetic analysis of Gnomoniopsis spp., Phomopsis spp. and Phoma spp. revealed their classification in three distinct groups (Fig. 3), and a very close relationship between the Gnomoniopsis sp. strains from this study and those found in GenBank derived from Dryocosmus galls (Viterbo) and chestnut rot in Italy (Torino - Gnomoniopsis castanea), Australia (Gnomoniopsis smithogilvyi) and New Zealand, as well as with strains from India whose host was not specified in the database (Fig. 3). The chestnut Gnomoniopsis sequences seem quite different from other Gnomoniopsis strains detected in the USA on other plant species. The Phomopsis castanea sequence is completely different from Gnomoniopsis ones; this strain derived from Castanea mollissima in China, but no other information are recorded.

\section{Artificial inoculation of nuts}

All fifteen nuts assayed to test their healthiness were found to be uncontaminated by moulds.

The Gnomoniopsis isolates tested engendered symptoms of brown rot and were detected in most (61 to $71 \%$ ) of the artificially infected nuts. No differences between the strains were evident (Tab. 6). The disinfected and wounded controls did not show any symptoms, while only two (13\%) of the wounded but non-disinfected controls showed initial symptoms of colonization by $P e$ nicillium sp.

\section{Discussion and conclusions}

A high degree of damage was found in all three orchards sampled and both black rot and brown rot fungi were common, especially in the Crosano orchard where more than half of the crop appeared to be affected by mould fungi. Insect damage was also severe, confirming its destructiveness in nut production.

Sclerotinia pseudotuberosa is known to be a ubiquitous endophyte capable of direct nuts colonization, starting with infection of the flowers (Vettraino et al. 2005). Warm, dry weather during the harvest period, as recorded in 2011, may have restricted the presence of the fungus in the nuts sampled. Indeed, several authors consider these conditions to be the main factors constraining the spread of black rot (Sieber et al. 2007, Delatour \& Morelet 1979, Ridé \& Gudin 1960). Nonetheless, it is worth noting that black rot was present in all the study areas and could pose a serious problem for nut storage in the absence of water-curing treatments (Migliorini et al. 2010).

The unusual spread of brown rot, the high incidence of damage caused by this disease and the extent of the damage found in Crosano justifies growers' worries about this disease, which has been highly destructive in other parts of Piedmont and Tuscany (Visentin et al. 2012, Poli, personal comm.). The presence of brown rot in fruits still in the burr exacerbates the already harmful impact of this disease and reduces the quality and quantity of chestnuts with consequences for the economic viability of cultivation.

Gnomoniopsis sp. was found to be the causal agent of brown rot in all three areas. In addition to genetic analyses, culture morphology and the shapes and sizes of conidia also confirm homology of the isolated strains with those recently found in association with D. kuriphilus galls in the Viterbo area (Monti Cimini - Magro et al. 2010). We were also able to confirm a complete homology with the newly described Gnomoniopsis castanea (Visentin et al. 2012) and Gnomoniopsis smithogilvyi (Shuttleworth et al. 2012, 2013). As suggested by Vannini et al. (2012) and Visentin et al. (2012), evidence by isolation from bark support a massive presence of this fungus as endophytic in one- and two-year-old shoots. This behavior could explain its ability to colonize gall tissue and to infect nuts still in burrs, maybe in bud burst. It could also explain its sudden appearance in various chestnut-growing areas of Italy, because probably already present on trees. Nevertheless, this fungus, like $S$. pseudotuberosa, was not reported in previous investigations on endophytism in chestnut shoots carried out in Switzerland (Bissegger \& Sieber 1994). Other fungi belonging to the Gnomoniopsis genus were also described as endophytic on Fagacae (Walker et al. 2010). It is worth noting that isolation of Gnomoniopsis was not related to bark alteration (cankers or necrosis) and that no fructification was observed on bark tissue in the present study, while pycnidia were found on galls instead. The common presence of this fungus on chestnut tissue suggests a possible role in checking gall wasp populations by colonizing the gall tissue and perhaps the insect inside chambers (Vannini et al. 2012), but its pathogenicity on fruits is a formidable constraint for its potential use as a bio-control agent.

According to the owner of the Crosano orchard, brown rot has been present since 2003 , although its presence has increased in the last three years. Its emergence does not appear to be related to the appearance of $D$. kuriphilus infestations in Trentino, which was first recorded in the province in 2007 and far away from the stand examined (Salvadori et al. 2007). The recent finding (January 2013) of Gnomoniopsis pycnidia on galls which remained overwintering on trees (Fig. 2f - Maresi G, personal comm.) calls for a more detailed investigation on the possible role of D. kuriphilus galls in the spread of the brown rot fungus.

Meteorological records report a warm, dry period in all the study areas during the 2011 vegetative season, but in the area least affected (Boarda) irrigation helped the trees. Stress and drought periods have been common in the Crosano area since 2003. Plant stress brought about by drought and gall 
wasp attacks may have favored brown ro spread in central and northern Italy. Afflicted and suffering chestnut trees are likely to be highly susceptible to infection by endophytes or latent pathogens such as Gnomoniopsis sp., as they have been to chestnut blight (Turchetti et al. 2010). In a context of climate change, new interesting perspectives arise for the concept of parasitism: asymptomatic fungi may become virulent and produce disease symptoms under certain environmental conditions (Brown et al. 1998, Slippers \& Wingfield 2007, Rodriguez et al 2009, Krabel et al. 2013). It is worth noting that temperatures around $27{ }^{\circ} \mathrm{C}$ are considered optimal for the growth of Phoma endogena, the causal agent of brown rot, according to Ridé \& Gudin (1960).

Gnomoniopsis sp. was isolated from initial brown decaying tissue, white chalky tissue and blackish fruiting bodies on decayed endosperm. There is a close correspondence between these symptoms and those of Phoma endogena, first described by Spegazzini (1879) on nuts in the Veneto region (northern Italy). Voglino \& Bongini (1917) gave an accurate account of the degradation of infected nuts collected in Piedmont, and the symptoms and pycnidia described, as well as the photographs, closely match those of Gnomoniopsis sp. Servazzi (1941) used the term "mummification" for the same phenomenon observed on nuts from the same area (Piedmont), while Ciferri (1951) reported that Servazzi's description corresponded with the symptoms he observed on nuts collected near Cuneo (Piedmont). He proposed the new name Phomopsis endogena based on the presence of a very few Phomopsis type $\beta$ conidia and suggested that $P$. endogena may be identical with Phomopsis viterbensis from the Viterbo area described by Camici (1948). Moreover, working with Voglino \& Bongini's (1917) original strains, he confirmed homology in morphology between Phoma and Phomopsis endogena. Ciferri also suggested that this fungus was already present in the nut during fructification and therefore in burrs. Remarkably, all these reports refer to the areas where the main attacks of Gnomoniopsis sp. are currently being observed. Ridé \& Gudin (1960) introduced the term "brown rot" (pourriture brune) and revived the name Phoma endogena for the absence of type $\beta$ conidia: their descriptions of the mycelium and symptoms closely match those reported by the aforementioned authors and those described in this paper. They also hypothesized that infection occurred at early fructification stages, that $P$. endogena was possibly endophytic, and that there was a relationship between the action of the fungus and warm temperature and dry conditions. Breisch (1995) and Pratella (1994) showed clear pictures of $P$. endogena attacks in their papers, which per- fectly match the symptoms observed in the present study. The same rot disease has also been ascribed to Gnomonia pascoe in New Zealand (Smith \& Agri 2008). Ho (pers. comm.) recently pointed out the genetic correspondence between $P$. castanea, $P$. endogena and Gnomoniopsis sp. in New Zealand, while in Australia Shuttleworth et al. (2012, 2013) put forward the name Gnomoniopsis smithogilvyi instead of $G$. pascoae for the agent of brown rot damage. Eventually, the same fungus was described in Piedmont as Gnomoniopsis castanea (Visentin et al. 2012). Unfortunately, no Phoma or Phomopsis endogena cultures or DNA sequences are recovered for comparison with Gnomoniopsis sp.

Montealegre \& Gonzalez (1986) in Chile and Washington et al. $(1997,1999)$ in Australia both indicated Phomopsis castanea as agents of brown rot in Castanea sativa orchards, though they did not describe or record type $\beta$ conidia. Phomopsis castanea was instead recovered from cankers on small branches and shoots of European chestnut but not on nuts (Saccardo 1879, 1884, 1931, Petrak 1921, Moriondo 1963, Belisario \& Scortichini 1993). Recently, a Phomopsis castanea mollissima was described on leaves but not on fruits of Castanea mollissima in China (Shu-Xia \& Hong-Bing 2010). On this basis, Smith \& Agri (2008) clearly distinguished between Phomopsis or Diaporthe castanea found on chestnut older branches and Gnomonia pascoe agent of brown rot, then described as Gnomoniopsis by Shuttleworth et al. (2012).

In conclusion, Phoma endogena, Phomopsis endogena, Gnomonia pascoe, Gnomoniopsis castanea, Gnomoniopsis smithogilvyi and Gnomoniopsis sp. have very similar morphological characteristics and pathogenic behavior, in that they have similar-sized pycnidia and conidia and are able to produce the same array of symptoms in chestnut nuts, being also all endophytic in bark tissues. Therefore, the hypothesis that they could be the same fungus is very plausible. Anyway, further studies on the taxonomy and genetics of these fungi are required, given that DNA analyses clearly separate the Phoma, Phomopsis and Gnomoniopsis groups. Nonetheless, Gnomoniopsis sp. is the agent involved in the current epidemic of brown rot, and recovered on D. kuriphilus galls in Italy, like the brown rot pathogen recorded in Australia. In the light of these findings, further researches are desirable to find new control strategies aimed to save production in the most affected areas. The need is urgent as there is a risk that a combination of various factors, such as the resurgence of blight due to climate stress, the expansion of the Asian chestnut gall wasp and crop destruction by fungi or insects, could set off a general decline in chestnut trees and or- chards or, even worse, in the entire chestnut production.

\section{Acknowledgements}

We would like to thank Giovanni Falchero, Paolo Miorelli, Luciano Massetti and Francesca Ugolini for technical assistance in the field and data processing.

\section{References}

Belisario A, Scortichini M (1993). Phomopsis castanea and Pseudomonas syringae pv. syringae associated with Castanea sativa seedling and stem cankers. In: "Proceedings of international congress on chestnut". Spoleto (Italy) 2023 Oct 1993. E. Antognozzi ed., Spoleto, Italy, pp. 541-544.

Bernardez MM, De la Montana MJ, Garcia QJ (2004). HPLC determination of sugars in varieties of chestnut fruits from Galicia (Spain). Journal of Food Composition and Analysis 17 (1) 63-67. - doi: 10.1016/S0889-1575(03)00093-0

Bissegger M, Sieber TN (1994). Assemblages of endophytic fungi in coppice shoots of Castanea sativa. Mycologia 86: 648-655. - doi: 10.2307/ 3760535

Bosio G, Gerbaudo C, Piazza E (2010). Dryocosmus kuriphilus Yasumatsu: an outline seven years after the first report in Piedmont (Italy). Acta Horticolture 866: 341-348.

Breisch H (1995). Châtaignes et marrons. Ctifl, Paris, France, pp. 239. [in French]

Brown KB, Hyde KD, Guest DI (1998). Preliminary studies on endophytic fungal communities of Musa acuminata species complex in Hong Kong and Australia. Fungal Diversity 1: 27-51.

Camici L (1948). La "mummificazione delle castagne" da Phomopsis viterbensis sp. Annali della Sperimentazione Agraria 2: 557-566. [in Italian]

Ciferri R (1951). La "mummificazione" delle castagne da Phomopsis endogena (Spe.) nobis, n. comb. Notiziario delle Malattie delle piante 8 36-37. [in Italian]

Conedera M, Jermini M, Sassella T, Sieber TN (2005). Raccolta, trattamento e conservazione delle castagne. Caratteristiche del frutto e principali agenti infestanti. Prima parte. Sherwood 11(107): 5-12. [in Italian]

Delatour C, Morelet M (1979). La pourriture noire des glands. Revue Forestiere Française 3 (2): 101-115. - doi: 10.4267/2042/21268

Ellis MB, Ellis JP (1997). Microfungi on land plants. An identification handbook. The Richmond Publishing, New York, USA, pp. 868.

Ferreira-Cardoso J, De Vasconcelos Mc (2009). Características comerciais e composição química básica das castanhas provenientes de clones híbridos da selecção do CENASEF. In: "Castanheiros híbridos - Estudos de resistência à doença da tinta" (Gomes-Laranjo J, Peixoto F, Ferreira-Cardoso J eds). Projecto Castaña/SP1.E9/ 02, Programa INTERREG III A Cooperação Transfronteiriça UTAD, Vila Real, GaliciaNorte, Portugal, pp. 8-17. [in Portuguese]

Gentile S, Valentino D, Visentin I, Tamietti G 
(2010). An epidemic of Gnomonia pascoe on nuts of Castanea sativa in the Cuneo area. Acta Horticolture 866: 363-368.

Gomes-Laranjo JA-AJ, Ferreira-Cardoso J, Pimentel-Pereira M, Abreu CG, Torres-Pereira J (2004). Effect of chestnut ink disease on photosynthetic performance. Journal of Phytopathology 152 (3) 138-144. - doi: 10.1111/j.14390434.2004.00814.x

Korel F, Balaban MO (2008). Chemical composition and health aspects of Chestnut (Castanea spp.). In: "Tree nuts: composition, phytochemicals, and health effects" (Alasalvar C, Shahidi F eds). CRC Press, Taylor \& Francis, Boca Raton, FL, USA, pp 171-184.

Krabel D, Morgenstern K, Herzog S (2013). Endophytes in changing environments - do we need new concepts in forest management? iForest 6 (2): 109-112. - doi: 10.3832/ifor0932-006

Magro P, Speranza S, Stacchiotti M, Martignoni D, Paparatti B (2010). Gnomoniopsis associated with necrosis of leaves and chestnut galls induced by Dryocosmus kuriphilus. New Disease Reports 21: 15.

Migliorini M, Funghini L, Marinelli C, Turchett T, Canuti S, Zanoni B (2010). Study of water curing for the preservation of marrons (Castanea sativa Mill. Marrone fiorentino cv). Postharvest Biology and Technology 56: 95-100. - doi: 10.1016/j.postharvbio.2009.12.001

Montealegre J, Gonzalez S (1986). Hongos causantes de pudricones en frutos de Castanea sativa Mill. Simiente 56: 166-169. [in Spanish]

Moriondo F (1963). Nuovi reperti fitopatologici. Annali Accademia Italiana Scienze Forestali 12 313-345. [in Italian]

Pedrazzoli F, Salvadori C, De Cristofaro A, Di Santo P, Endrizzi E, Sabbatini Peverieri G, Roversi PF, Ziccardi A, Angeli G (2012). A new strategy of environmentally safe control of chestnut tortricid moths. IOBC/WPRS Bulletin 74 117-123.

Petrak F (1921). Uber Fusicoccum castaneum. Sacc. Annales Mycologica XIX: 205-207.

Pratella GC (1994). Note di bio-patologia e tecnica della conservazione e trasporto: marroni e castagne. Rivista di Frutticoltura 56 (4): 75-77. [in Italian]

Ridé M, Gudin C (1960). Sur la biologie de quelques champignons parasites de la ch'taigne et plus particulerement de Phoma endogena (Speg.). Comptes-rendus des Seances de l'Academie d'Agriculture de France 46: 536543. [in French]

Rodriguez RJ, White JF, Arnold AE, Redman RS
(2009). Fungal endophytes: diversity and functional roles. New Phytologist 182: 314-330. doi: 10.1111/j.1469-8137.2009.02773.x

Saccardo PA (1879). Fungi Gallici lecti a cl. viris P. Brunaud, C.C. Gillet et Abb. Letendre. Michelia 1: 500-538.

Saccardo PA (1884). Sylloge fungorum 3: 249250.

Saccardo PA (1931). Sylloge fungorum 25: 230.

Salvadori C, Maresi G, Tessari L (2007). Il cinipide galligeno del castagno. Terra trentina 53 (9): 24-29. [in Italian]

Servazzi O (1941). Appunti di fitopatologia: VII intorno alle muffe delle castagne. Bollettino Laboratorio. Sperimentale Regio Osservatorio Fitopatologico 17: 39-44. [in Italian]

Shuttleworth LA, Liew ECY, Guest DI (2012) Gnomoniopsis smithogilvyi Fungal Planet 108. In: "Fungal Planet Description Sheets: 107-127" (Crous PW, Summerell BA, Shivas RG, Burgess TI, Decock CA, Dreyer LL, Granke LL, Guest DI, Hardy GEStJ, Hausbeck MK, Hüberli D, Jung T, Koukol O, Lennox CL, Liew ECY, Lombard L, McTaggart AR, Pryke JS, Roets F, Saude C, Shuttleworth LA, Stukely MJC, Vánky K, Webster BJ, Windstam ST, Groenewald JZ eds). Persoonia 28: 107-127. - doi: 10.3767/0031585 $12 \times 652633$

Shuttleworth LA, Liew ECY, Guest DI (2013). Survey of the incidence of chestnut rot in southEastern Australia. Australasian Plant Pathology 42(1): 63-72. - doi: 10.1007/s13313-012-0170-2 Shu-Xia J, Hong-Bing MA (2010). A new species of Phomopsis on Castanea mollissima. Mycosystema 29(4): 467-471.

Sieber TN, Jermini M, Conedera M (2007). Effects of the harvest method on the infestation of chestnuts (Castanea sativa) by insects and moulds. Journal of Phytopathology 155: 497504. - doi: 10.1111/j.1439-0434.2007.01269.x

Slippers B, Wingfield MJ (2007). Botryosphaeriaceae as endophytes and latent pathogens of woody plants: diversity, ecology and impact. Fungal Biology Reviews 21: 90-106. - doi: 10.1016/j.fbr.2007.06.002

Smith HC, Agri M (2008). The life cycle, pathology and taxonomy of two different nut rot fungi in chestnut. Australian Nutgrower 22 (2): 11-15. Spegazzini C (1879). Nova addenda ad Mycologiam Venetam. Michelia 1(5): 453-487.

Stanosz GR, Blodgett JT, Smith DR, Kruger EL (2001). Water stress and Sphaeropsis sapinea as a latent pathogen of red pine seedlings. New Phythologist 149: 531-538. - doi: 10.1046/j.14 69-8137.2001.00052.x
Turchetti T, Addario E, Maresi G (2010). Interactions between chestnut gall wasp and blight: a new criticality for chestnut. Forest@ 7 (1): 252 258. - doi: 10.3832/efor0642-007 [in Italian with English summary]

Turchetti T, Ferretti F, Maresi G (2008). Natural spread of Cryphonectria parasitica and persistence of hypovirulence in three Italian coppiced chestnut stands. Forest Pathology 38 (4): 227 243. - doi: 10.1111/j.1439-0329.2008.00557.x Vannini A, Martignoni D, Caccia R, Bruni N, Tomassini A, Paparatti B, Speranza S, Aleandri MP, Vettraino AM (2012). Biological control of chestnut gall wasp by endophitic fungus Gnomoniopsius sp. In: Proceedings of the "Fifth International Chestnut Symposium". Shepherdstown (WV - USA) 4-8 Sept 2012. ISHS Press, Leuven, Belgium (in press).

Vettraino AM, Paolacci A, Vannini A (2005). Endophytism of Sclerotinia pseudotuberosa: PCR assay for specific detection in chestnut tissues. Mycological Research 109: 96-102. - doi: 10.1017/S0953756204001583

Visentin I, Gentile S, Valentino D, Gonthier P, Tamietti G, Cardinale F (2012). Gnomoniopsis castanea sp. nov (Gnomoniaceae, Diaporthales) as a causal agent of nut rot in sweet chestnut. Journal of Plant Pathology 94: 411-419.

Voglino P, Bongini V (1917). Phoma endogena, parassita delle castagne. Annali Regia Accademia Agricoltura 60: 3-12. [in Italian]

Walker D, Castlebury LA, Rossman AY, Sogonov M, White J (2010). Systematics of the genus Gnomoniopsis (Gnomoniaceae, Diaporthales) based on a three gene phylogeny, host associations, and morphology. Mycologia 102: 1479 1496. - doi: 10.3852/10-002

Washington WS, Stewart-Wade S, Hood V (1999). Phomopsis castanea, a seed-borne endophyte in chestnut trees. Australian Journal of Botany 47: 77-84. - doi: 10.1071/BT97023 Washington WS, Allen AD, Dooley LB (1997). Preliminary studies on Phomopsis castanea and other organisms associated with healthy and rotted chestnut fruit in storage. Australian Journal Plant Pathology: 26: 37-43. - doi: 10.1071/AP 97006

White TJ, Bruns T, Lee S, Taylor J (1990). Amplification and direct sequencing of fungal ribosomal DNA for phylogenetics. In: "PCR Protocols: a guide to methods and applications" (Innis MA, Gelfand DH, Sninsky JJ, White TJ eds). Academic Press, San Diego, CA, USA, pp. 315322 . 